\title{
Financial Contracting and the Choice between Private Placement and Publicly Offered Bonds
}

\author{
Simon Kwan \\ Federal Reserve Bank of San Francisco \\ and \\ Willard T. Carleton \\ University of Arizona
}

Working Paper 2004-20

http://www.frbsf.org/publicatio ns/economics/papers/2004/wp04-20bk.pdf

The views in this paper are solely the responsibility of the authors and should not be interpreted as reflecting the views of the Federal Reserve Bank of San Francisco or the Board of Governors of the Federal Reserve System. 


\title{
Financial Contracting and the Choice between Private Placement and Publicly Offered Bonds
}

\author{
Simon H. Kwan \\ Economic Research Department \\ Federal Reserve Bank of San Francisco \\ 101 Market Street, San Francisco, CA 94105 \\ Telephone (415) 974-3485 \\ Fax (415) 974-2168 \\ E-mail address: simon.kwan@sf.frb.org \\ and \\ Willard T. Carleton \\ Department of Finance \\ College of Business and Public Administration \\ University of Arizona \\ Tucson, AZ 85721 \\ Telephone (520) 621-1520
}

November, 2004

All comments welcome.

Preliminary, please do not quote without permission.

We thank Teachers Insurance and Annuity Association for providing the data on private placement bonds, Merrill Lynch \& Co. and Jerome Fons of Moody's Investor Services for providing the data on publicly offered bonds, participants at the Federal Reserve System Conference and the AFA Annual Meeting for helpful comments. The views expressed in this paper represent the authors' views only and do not necessarily represent the views of the Federal Reserve Bank of San Francisco or the Federal Reserve System. 


\section{Financial Contracting and the Choice between Private Placement and Publicly Offered Bonds}

\section{Abstract}

Private placement bonds have unique financial contracting in controlling borrower-lender agency conflicts due to direct monitoring and the relative ease of future renegotiation. Our data show that private placements are more likely to have restrictive covenants and are more likely to be issued by smaller and riskier borrowers. We find the determinants of bond yield spreads to be quite different between private placements and public issues, reflecting the different institutional arrangements between the two markets. Finally, in issuing bonds, we find that firms self-select the bond type to minimize both the financing costs and the transaction costs. 


\section{Introduction}

A private placement bond is a non-underwritten, unregistered corporate bond sold directly to a single investor or a small group of investors. From 1985 to 1995,23 percent of the $\$ 4.3$ trillion corporate bonds issued by U.S. corporations was privately placed, clearly indicating that private placement bonds represent an important source of funds to U.S. corporations. ${ }^{1}$ However, research on the structure and pricing of private placement corporate bonds is somewhat limited. Analyses of how firms choose between issuing bonds privately versus publicly are even more rare. In this paper, we employ a large dataset of private placement and publicly offered bonds to shed light on these two issues.

There were a number of studies that examined the choice between private and public debt, including Houston and James (1996), Krishnaswami, Spindt, and Subramaniam (1999), Cantillo and Wright (2000), and Denis and Mihov (2003). However, within the class of private debt, none of these studies, with the exception of Denis and Mihov, made the distinction between bank loans and private placement bonds. ${ }^{2}$ In this paper, we study only private placement bonds and exclude bank loans for the following reasons. First, banks are protected by the bank safety net and are subject to extensive banking regulations while private placement investors are not,

${ }^{1}$ Our empirical analysis is based on private placement data between 1985 to 1994 obtained from Teachers Insurance and Annuity Association. More recent data are not available to us.

2 In Denis and Mihov (2003), their nonbank private debts were mainly Rule 144A private placements that can be traded among institutional investors. We exclude Rule 144A private placements in this paper and study only non-144A private placements that have no secondary market. Please also see footnote 10 in section III. 
implying important differences between the two types of lenders. ${ }^{3}$ Second, bank loans tend to be structured somewhat differently than private placement bonds. For example, bank loans tend to have shorter maturity and are usually floating-rate loans whereas private placement bonds have maturity and pricing conventions much closer to publicly offered bonds. ${ }^{4}$ Thus, in the spectrum of private debts, bank loans are arguably less directly comparable to public market bonds than private placement bonds. In focussing on just private placement bonds, our analysis will not be confounded by the uniqueness of bank loans.

Regarding the structure of private placement bonds, Zinbarg (1975) and Smith and Warner (1979) argued that covenants in private placements tend to be more restrictive than public issues. ${ }^{5}$ El-Gazzar and Pastena (1990) and Laber (1992) empirically examined the frequency of different types of covenants in private placements. Although drawn from relatively small samples, their results did show that private placement covenants tend to be tighter than public bond covenants. ${ }^{6}$ With micro data on a much larger sample of private placement and public bonds, our analysis also indicates that private placements are more likely to have restrictive covenant provisions than public issues.

Furthermore, we show that firms that borrow from both the public and the private

${ }^{3}$ Indeed, studies by James (1987) and Lummer and McConnell (1989) suggested that there is something unique about bank loans but not private placement debts.

${ }^{4}$ See for example, Carey, Prowse, Rea, and Udell (1993).

5 Hereafter, private placements refer to privately placed corporate bonds, and public issues refer to publicly offered corporate bonds.

${ }^{6}$ Hawkins (1982), however, does not find a relationship between the restrictiveness of covenants in his small sample of private placements and the quality of the borrower. 
placement markets, referred to as "switchers," are fundamentally different from firms that borrow only from the private market, referred to as "non-switchers." For example, we find that switchers tend to be larger and have higher credit risk ratings than non-switchers. Hence, it is also important to distinguish between private placements issued by switchers and those issued by nonswitchers. While significant differences in contract features between switchers' and nonswitchers' private placements are found, it is worth noting that there are also significant differences between switchers' private placements and public issues.

Regarding the pricing of private placement bonds and firms' issuance choice, Zwick (1980) suggested that private placements seem to cost more than public issues but did not model the pricing of private placement bonds, nor the firm's borrowing decision. Blackwell and Kidwell (1988) found that the yield spreads between private placements and public bonds issued by utility companies were related to interest rate volatility, and suggested that firms were trying to minimize borrowing costs by selecting the market providing the lowest transaction costs. In this paper, we allow for complete interaction between bond pricing and issuance type, and we explicitly model the self-selectivity problem with regard to firms' issuance choice for those that access both the private and public bond markets. While we also find that firms choose between private placements and public issues to minimize financing costs, our results suggest that the yield spread between private placement and public bonds is attributable to the somewhat different pricing schemes between the two markets, rather than to external market conditions. In addition, we find that for switchers, the choice between issuing private placements and public issues is related to the bond issue size and the borrowing firm's financial leverage, but not to the potential difference in bond yield spread between the two markets. 
The rest of the paper is organized as follows. Section II compares the areas of contract design, lender monitoring, and debt renegotiation between the private placement market and the public bond market. Section III describes the data used in this study. Descriptive statistics of contract characteristics and firm characteristics are presented in section IV. Section V studies the determinants of yield spread in private placement and public bonds, while simultaneously modelling borrowing firms' issuance choice. Section VI concludes this study.

\section{Private placements versus public offerings}

Private placement bonds differ from publicly offered bonds in three key areas: (1) the design of bond covenants, (2) credit monitoring, and (3) the relatively ease of renegotiation. Theoretical work by Diamond (1991), Berlin and Loeys (1988), Berlin and Mester (1992), and Chemmanur and Fulghieri (1994) suggested that private debts, whose terms could be modified throughout the life of the debt contract upon mutual agreement between the borrower and the lender, are more likely to have restrictive covenants than public debts. In fact, in a public bond offering, a debt security is sold at a fixed price to the public on a take-it-or-leave-it basis. Investors in a public offering do not participate in shaping the bond's contract features, though their interests will be solicited by bond salespeople from the investment banker. Whereas in private placements, the lender often influences the structure of the debt contract. In particular, when only one lender is involved in a private debt issue, the convenience (especially if the contract is anticipated to require modifications during the life of the loan) of dealing with a sole lender gives the lender some bargaining advantages, who therefore can have considerable input into the final jointly acceptable loan contract. If the bond issue is large and must be syndicated, 
the lead lender in the syndicate usually has some influence on the terms of the final contract. Thus, while public bond issues usually contain mostly standardized "boilerplate" covenant provisions [Smith and Warner (1979)], private placements tend to have more restrictive covenants that are customized to fit the unique borrowing situation. In addition to the negative covenants that are used predominantly in public issues, private placements often adopt affirmative (maintenance) covenants which require the borrowing firm to maintain (and report on) certain minimum standards of financial soundness. Appendix 1 presents a summary of the proposed terms of a representative private placement bond made by a privately held company.

For publicly issued bonds that are held by a large number of bondholders, costly loan monitoring results in either duplication of effort when each lender monitors directly or a freerider problem when no lender monitors [Diamond (1984)]. In practice, the covenants of publicly offered bonds are enforced by the bond's trustee who is appointed and paid by the borrowing firm, and the borrowing firm's repayment capacity is monitored by third party bond-rating agencies. $^{7}$ In contrast, private placement bonds are monitored directly and primarily by the private lender(s), who has little to no free-rider problem in loan monitoring. Almost all private placement investors are institutional lenders who have expertise and scale economies in credit monitoring. Failure to meet the bond covenant provisions subjects the borrowing firm to technical default. Except in the case of financial distress, modification of a public bond covenant

7 Smith and Warner (1979) argued that "the trustee will not act entirely in the bondholders' interest. This is particularly true because the extent to which the trustee can be held negligent is limited: while the trustee must act in good faith, his responsibilities often go no further unless there is a default. Under the Trust Indenture Act, when a default has occurred, the trustee is only required to "use the same degree of care and skill ... as a prudent man would exercise' in enforcing the covenants." 
to alleviate default is virtually impossible because it requires unanimous bondholder consent under the Trust Indenture Act. However, in private placements, technical default and renegotiation of bond covenants occur quite frequently [Beneish and Press (1993) and Chen and Wei (1993)]. During the renegotiation of private placement bonds, the information exchange between the borrower and the lender can be viewed as an integral part of loan monitoring. Thus, the combination of restrictive covenants, ex post renegotiation, and direct credit monitoring make private placement bonds particularly effective in controlling agency conflicts between borrowers and lenders, implying that these credit instruments are particularly well suited for high risk borrowers.

\section{Data}

To study private placement bonds, we obtain data from Teachers Insurance and Annuity Association (TIAA) on all privately placed bonds that were approved by its finance committee between January 1985 and December $1994 .^{8}$ All convertible bonds, variable-rate bonds, and bonds with equity features such as warrants or rights are eliminated, leaving only fixed-rate, straight bonds in our sample. All Rule 144a-private placements (as stated in the offering proposal) are also excluded because, unlike non-144a private placements, Rule 144a-private placements are structured to facilitate inter-institutional trading in the secondary market and

8 As of 1995, TIAA was the third largest life insurance company in the U. S. in terms of general account assets. Together with College Retirement Equities Fund, they made up the largest private pension system in the U.S. TIAA has been one of the major lenders in the private placement bond market, and a large majority of sample private placement bonds were brought to TIAA by investment bankers. 
therefore tend to resemble publicly offered bonds more than traditional, non-144a private bonds. ${ }^{9}$ Occasionally, the issuing firm offered a package of straight debt securities, distinguished by contract terms, maturity tranches, and covenant packages, in a single private placement offering. For the purpose of this study, each constituent security in the offering is treated separately because the contract terms are different. The final sample consists of 658 private placement bonds issued by 466 firms. Assuming firms that had publicly issued bond(s) on their balance sheets at the time of the private placement were switchers, 123 private placements were issued by 89 switchers, and the remaining 535 private placements were issued by 377 non-switchers.

In order to compare private placement bonds to public bonds, we also collect an independent sample of publicly issued corporate bonds from Merrill Lynch's proprietary fixedincome securities database, which includes all publicly traded corporate bonds that are quoted in the Bloomberg terminal. Similar to the private placement sample, we include only fixed-rate, straight bonds in the public bond sample. The final public bond sample consists of 1,643 public bonds issued by 414 publicly held companies.

\section{Contract and firm characteristics}

\section{$\underline{\text { A. Contract Characteristics }}$}

Table 1 provides descriptive statistics for the sample private placement and publicly offered bonds. Private placement bonds are also grouped according to whether they were issued

9 In 1990, the Securities and Exchange Commission adopted Rule 144a permitting interinstitutional sale of unregistered securities in order to establish secondary markets for private placement securities. See also Fenn (2000) for important qualitative differences between 144a and non-144a private placements. 
by switchers or non-switchers. To test whether the structure of private placement bonds is systematically different from that of publicly offered bonds, bivariate comparisons of contract characteristics between the two samples of private and public bonds are conducted using the nonparametric Wilcoxon Rank Sum test for continuous variables, and the Chi-square test for discrete variables. Furthermore, to test whether the structure of private placement bonds issued by switchers and non-switchers are systematically different, we conduct the same tests across the two sub-samples of private placement bonds.

Private placement bonds are usually issued at par value. As illustrated in Appendix 1, the coupon rate and hence the computed yield-to-maturity based on a par value price are set relative to the interpolated yield-to-maturity of actively traded Treasury securities with maturity equal to the private placement's average life, which is the weighted average maturity of the principal after taking the mandatory redemption into consideration. ${ }^{10}$ In the private placement sample, the yield spread in excess of similar maturity Treasuries averages 2.02 percent with the median yield spread at 1.55 percent. The average yield spread for the sample public bonds is only 1.13 percent with the median yield spread at 1.05 percent. ${ }^{11}$ The Wilcoxon Rank Sum test rejects the hypothesis that the yield spreads in both the public and the private samples have the same

${ }^{10}$ Note that this pricing format does not formally address the possibility of a significant duration difference between the corporate bond and the Treasury bond. Pricing off Treasuries as of the "date of circle," the offering date, eliminates any price adjustment at the take-down date due to daily market interest rate fluctuations, but it exposes both the borrower and the lender to interest rate risk relative to the take-down date.

${ }^{11}$ The yield spread for publicly offered bonds is equal to the bond's offering yield in excess of the interpolated yield-to-maturity of actively traded Treasuries with matching term-tomaturity, for both sinking fund and non-sinking fund bonds. We do not have information on the sinking fund bonds' sinking fund schedules. 
distribution. While removing non-switchers' issues from the private placement sample narrows the yield spread difference substantially, the difference in yield spread between switches' private placements and publicly issued bonds remains statistically significant.

The mean (median) issue size of the sample private placements is $\$ 65.11$ million $(\$ 40$ million). Compared to the mean (median) issue size of \$154.31 (\$125) million for the public sample, private placements are significantly smaller. Note that the difference in issue size between switchers' and non-switchers private placements is insignificant.

The mean (median) maturity of the sample public bonds is 14.97 (10) years. Private placements, on average, have shorter maturities, with mean (median) maturity of 11.21 (10) years. However, the difference in maturity is driven by non-switchers' private placements, as evidenced by the insignificant maturity difference between switchers' private placements and public bonds.

Turning to bond covenants, private placements are significantly more likely to have a call provision than public issues. Over 90 percent of our sample private placements are callable, compared to only 40 percent in the public sample. A call provision can be used to mitigate certain agency conflicts between borrowers and lenders, such as the under-investment problem described in Myers (1977). ${ }^{12,} 13$ Furthermore, in private placement bonds that tend to have more restrictive covenants, borrowing firms may want to use the call feature as an option to seek relief from those covenants. Thus, the prevalence of restrictive covenants in private placements may

12 See also Bodie and Taggart (1978), Barnea, Haugen, and Senbet (1980), and Robbins and Schatzberg (1986).

13 Thatcher (1985) found that firms with large agency costs of debts are more likely to issue callable bonds. 
actually lead to wider adoption of call provisions. Note that within the sample of private placement bonds, a call option is more likely to be found in non-switchers' than switchers' bond issues, and the difference is significant.

Further down in Table 1, over 60 percent of the sample private placement bonds are callable at the so called "makewhole" price, which is equal to the greater of the par value or the net present value of the remaining cash flows discounted at the prevailing similar-maturity Treasury rates plus a yield premium (see Appendix 1 for an illustration). Since the makewhole call price decreases with the level of interest rates, it has the effect of transferring the refinancing gains from the borrower to the lender. To the extent that the makewhole call option limits or eliminates all together the gains from refinancing to the borrower, it further suggests that the motivation for the call option may be to insure against covenants that could become unduly restrictive in the future. Within the sample of private placement bonds, a makewhole call is again more likely to be found in non-switchers' than switchers' issues.

The incidence of put option is significantly higher in the private placement sample than in the public sample. In the private sample, 24.5 percent of the private bonds have a put option, as compared to a mere 3.1 percent in the public sample. A put option gives bondholders the right to put the bond issue to the borrower at the pre-specified price when certain pre-specified events occur, protecting bondholders against event risks. While the difference in the incidence of put option between the private and the public samples is statistically significant, no significant difference is detected between switchers' and non-switchers private placements.

Regarding sinking fund provisions, 77.3 percent of the sample private placements have a sinking fund provision, which is significantly higher than the 10.2 percent observed in the public 
sample. Sinking fund reduces the lender's exposure in parallel with the expected decline in the value of the assets financed by the debt [Myers (1977)]. Sinking fund also reduces the possibility that any dividend constraint may entail additional investment even when no profitable projects are available [Smith and Warner (1979)]. While the incidence of sinking fund is significantly higher among private placements than public issues, no significant difference in this contract provision between switchers' and non-switchers' private placements is detected.

Finally, the proportion of sample private placement bonds that were secured by firm assets is 32.5 percent, which is significantly higher than what is found in the public sample, at 22.4 percent. Secured debts limit the borrower's ability to engage in asset substitution [Smith and Warner (1979)], and provides the lender with the first claim on the underlying collateral in the event of a default. Again, while the incidence of asset security is significantly higher in the private placement sample than in the public sample, within the sample of private placement bonds, the difference in the incidence of asset security between switchers' and non-switchers' private placements is insignificant.

The results in Table 1 indicate significant differences in the structure of private placement and public bonds. The findings are generally consistent with private placement bonds having more restrictive covenants than public bonds, and this remains to be the case even when only switchers' private placements are considered. Of course, the differences in contract characteristics could be the result of the systematic differences in firm characteristics across the two market, which are discussed next.

\section{B. Firm Characteristics}

In this subsection, we compare two important aspects of firm characteristics between 
private placement and public bond issuers. They are credit risk rating and firm size. Regarding bond ratings, in general, private placement bonds are not rated by bond rating agencies. ${ }^{14}$

However, because insurance companies are major investors in the private bond market, private placements received a credit risk rating by the National Association of Insurance Commissioners (NAIC). The NAIC ratings are used by the Commission to determine the amount of reserves, known as mandatory securities valuation reserve (MSVR), that must be held by an insurance company against its risky assets. While the MSVR requirement has been enforced by the NAIC for a long time, the current rating system, which corresponds to public debt ratings as shown below, has been effective only since 1990 .

\begin{tabular}{ccc}
\hline NAIC Rating & $\begin{array}{c}\text { Moody's / S \& P } \\
\text { Bond Rating }\end{array}$ & $\begin{array}{c}\text { MSVR Requirement } \\
(\%)\end{array}$ \\
\hline 1 & Aaa/AAA to A/A & 1 \\
2 & Baa/BBB & 2 \\
3 & $\mathrm{Ba} / \mathrm{BB}$ & 5 \\
4 & $\mathrm{~B} / \mathrm{B}$ & 10 \\
5 & $\mathrm{Caa} / \mathrm{CCC}$ or below & 20 \\
\hline
\end{tabular}

For private placements that were issued before the current rating system was in place, we converted their old NAIC rating into the current rating scale based on the MSVR requirement. ${ }^{15}$

${ }^{14}$ While the creditworthiness of switchers can be proxied by their public bond ratings, non-switchers by definition do not have public bond ratings. Furthermore, financial information of non-switchers, many of which are privately held, is generally unavailable so that it is not feasible to estimate their bond ratings using statistical models.

15 The old system classifies bonds into four rating categories with the highest quality issue subject to a 2 percent MSVR requirement, instead of the current 1 percent [see Society of Actuaries (1996)]. We assume private placements with a 2 percent MSVR under the old rating system would receive a NAIC 1 rating under the current system. 
For bonds in the public sample, we map their public bond ratings to NAIC ratings according to the above table.

Table 2 depicts the distribution of NAIC credit risk rating for our sample private placements and public issues. In the public sample, 73 percent of public issues have the equivalent of NAIC-1 rating and 26 percent have the NAIC-2 equivalent. Together, 99 percent of the public bonds in our sample are of investment grade quality, i.e., rated NAIC-2 or higher. In the private sample, only 66 percent of the sample private placements are investment grade quality: 44 percent rated NAIC- 1 and 22 percent rated NAIC-2. ${ }^{16}$ Of the remaining 34 percent, 21 percent have the lowest NAIC-5 credit rating, as compared to none in the public sample. The weighted average NAIC rating for the private placement sample is 2.4 , almost twice as high as the 1.28 average for the public bond sample. The chi-square test rejects the hypothesis that the distributions of NAIC rating between the private placement sample and the public bond sample are similar.

However, within the private placement sample, there is a significant difference in the distribution of the NAIC rating between switchers' and non-switchers' private placements. In the switchers' sub-sample, 86 percent have investment grade rating, while only 62 percent in the non-switchers' sub-sample are rated at or above NAIC-2. Furthermore, 25 percent of nonswitchers' issues have the lowest NAIC-5 rating, as compared to only 3 percent among switchers'. The weighted average NAIC rating for the non-switchers sub-sample is 2.6 , which is substantially higher than the 1.54 average for the switchers sub-sample. Although the chi-square

${ }^{16}$ Assuming all private placements with a 2 percent MSVR under the old rating system are rated NAIC-2, the percentages of NAIC- 1 and NAIC- 2 rated issues would be 12.6 percent and 53.9 percent, respectively. 
test also rejects the hypotheses that the two sub-samples of private placements have similar credit risk distribution as the public sample, switchers' private placements nonetheless have close resemblance to publicly offered bonds in the distribution of credit risk.

Table 3 reports the firm size of the borrowers in both the public and private samples.

Measured by total assets, the average borrower in the private sample is about one-fifth the size of the average borrower in the public sample. Within the sample of private placements, nonswitchers tend to be much smaller than switchers. The Wilcoxon Rank Sum test rejects the hypothesis that switchers and non-switchers have similar size distribution at the $1 \%$ level, but fails to reject the hypothesis that switchers and firms in the public sample have similar asset size. Using annual sales revenues to measure firm size provides qualitatively identical results.

\section{Bond pricing and borrowing choice}

In this section, we investigate jointly the pricing of privately placed and publicly offered corporate bonds and the determinants of firms' issuance choice. In making its financing decision, we assume that a firm chooses to issue bonds privately or publicly based on the considerations about the bond yield, covenant provisions, issuance cost, and the condition of the bond market. To issue bonds publicly, a firm incurs flotation costs, including a registration fee with the Securities and Exchange Commission, underwriter compensation, legal and professional fees, a trustee's fee, and printing and engraving outlays. Private placement of securities avoids all those fees except those due to investment bankers, who may be hired to assist finding buyers 
or forming lending syndicates. ${ }^{17}$ The contract terms, yield-to-maturity, and bond type (i.e., private versus public), are assumed to be jointly determined, given the issue size, term-tomaturity, and bond market condition.

\section{A. The Model}

Let $Y_{\mathrm{ui}}$ and $\mathrm{Y}_{\mathrm{pi}}$ be the public and private placement bond yields for the ith firm, and let $\rho_{\mathrm{i}}$ be the reservation yield differential which summarizes the ith firm's specific preferences. The firm is assumed to issue private placement bonds if:

$$
\frac{Y_{u i}-Y_{p i}}{Y_{p i}}>\rho_{i}
$$

In other words, the ith firm issues private placement bonds if the percentage yield differential between public and private bonds exceeds its reservation yield differential. The reservation yield differential, $\rho_{\mathrm{i}}$, summarizes firm i's receptivity to issuing private placement bonds; it captures the differences in both the financial contracting (discussed in section II) and flotation costs between private placements and public bonds. Depending on firm i's agency costs of debt and hence its demand for financial contracting, $\rho_{\mathrm{i}}$ can be either positive or negative. Specifically, we assume that $\rho_{\mathrm{i}}$ is a function of both firm characteristics and the difference in flotation cost between issuing bonds privately and publicly. As a first order approximation, therefore,

$$
\rho_{\mathrm{i}}=\alpha \mathrm{X}_{\mathrm{i}}+\beta \mathrm{C}_{\mathrm{i}}+\varepsilon_{1 \mathrm{i}}
$$

17 Blackwell and Kidwell reported that total flotation costs per $\$ 1,000$ bond on average are almost 50 percent higher in public issues than in private placements. 
where $\mathrm{X}_{\mathrm{i}}$ is a vector of firm characteristics, $\mathrm{C}_{\mathrm{i}}$ is an index which summarizes the monetary costs and non-pecuniary costs of private placement debts, and $\varepsilon_{1}$ is random error. $\varepsilon_{1}$ is assumed to be normally distributed with mean zero and variance $\sigma^{2}{ }_{\mathrm{i} \varepsilon}$.

Firms with high agency costs of debt may demand restrictive covenants and lender monitoring to increase the value of the firm [Jensen and Meckling (1976), Smith and Warner (1979)]. Other firms with high growth opportunities may demand flexibility in future contract renegotiation. Thus, as the first step, $\mathrm{C}_{\mathrm{i}}$ is modelled to be dependent on firm characteristics. Since the differences in flotation costs between issuing bonds privately and publicly are dependent on bond attributes, such as issue size, we model $\mathrm{C}_{\mathrm{i}}$ also to be dependent on contract characteristics. Finally, Blackwell and Kidwell found that the cost differences between public sale and private placement of utility bonds were related to the condition of the bond market. $\mathrm{C}_{\mathrm{i}}$, therefore, is modelled to be also dependent on bond market condition as well. Hence, we assume

$$
C_{i}=\gamma_{1}+\gamma_{2} X_{i}+\gamma_{3} Z_{i}+\gamma_{4} M_{i}+\varepsilon_{2 i}
$$

where $\mathrm{X}_{\mathrm{i}}$ is a vector of firm characteristics, $\mathrm{Z}_{\mathrm{i}}$ is a vector of contract characteristics, and $\mathrm{M}_{\mathrm{i}}$ is a vector of market condition variables. $\varepsilon_{2}$ is random error which is assumed to be normally distributed with mean zero and variance $\sigma_{2 \varepsilon}^{2}$. Thus, firm i will issue bonds privately if

$$
\frac{Y_{u i}-Y_{p i}}{Y_{p i}}>\left(\alpha+\beta \gamma_{2}\right) X_{i}+\beta \gamma_{1}+\beta \gamma_{3} Z_{i}+\beta \gamma_{4} M_{i}+\varepsilon_{1 i}+\beta \varepsilon_{2 i} .
$$

This criterion may be written in the form of a probit model:

If $\mathrm{I}_{\mathrm{i}}{ }^{*}>0$, then firm $\mathrm{i}$ issues private placement bonds; otherwise it issues public bonds, where 


$$
\mathrm{I}_{\mathrm{i}}^{*}=\delta_{0}+\delta_{1}\left(\frac{\mathrm{Y}_{\mathrm{ui}}-\mathrm{Y}_{\mathrm{pi}}}{\mathrm{Y}_{\mathrm{pi}}}\right)+\delta_{2} \mathrm{X}_{\mathrm{i}}+\delta_{3} \mathrm{Z}_{\mathrm{i}}+\delta_{4} \mathrm{M}_{\mathrm{i}}-\varepsilon_{\mathrm{i}}
$$

Finally, we specify the following models for bond yield spreads:

$$
\begin{aligned}
& Y_{u i}=\theta_{u 0}+\theta_{u 1} Z_{u i}+\theta_{u 2} M+\varepsilon_{u i}, \\
& Y_{p i}=\theta_{p 0}+\theta_{p 1} Z_{p i}+\theta_{p 2} M+\varepsilon_{p i},
\end{aligned}
$$

where $\mathrm{Y}_{\text {ui }}, \mathrm{Y}_{\mathrm{pi}}$ are the public and private bond yield spreads over similar maturity Treasuries, respectively, for the ith firm; $Z_{\mathrm{ui}}, \mathrm{Z}_{\mathrm{pi}}$ are respectively the attributes of the public and private placement bonds; and $\mathrm{M}$ is the vector of bond market condition variables. $\varepsilon_{\mathrm{u}}$ and $\varepsilon_{\mathrm{p}}$ are random errors which are assumed to be $\mathrm{N}\left(0, \sigma_{\mathrm{u}}^{2}\right)$ and $\mathrm{N}\left(0, \sigma_{\mathrm{p}}^{2}\right)$, respectively. Note that we allow complete interactions between bond yield spreads and bond types by specifying one equation for private placement bonds and one equation for public bonds.

In estimating the model, the natural logarithm of the yield-to-maturity of the corporate bond in excess of the interpolated yield-to-maturity of actively traded Treasury securities is used as the dependent variable in the bond pricing equations. Since $\log \mathrm{Y}_{\mathrm{ui}}-\log \mathrm{Y}_{\mathrm{pi}}$ is approximately equal to $\left(\mathrm{Y}_{\mathrm{ui}}-\mathrm{Y}_{\mathrm{pi}}\right) / \mathrm{Y}_{\mathrm{pi}}$, we rewrite the model in terms of this variable, which simplifies the estimation and is consistent with the theory. Thus, the model to be estimated consists of the following three equations:

$$
\begin{aligned}
& \log Y_{u i}=\theta_{u 0}+\theta_{u 1} Z_{u i}+\theta_{u 2} M+\varepsilon_{u i}, \\
& \log Y_{p i}=\theta_{p 0}+\theta_{p 1} Z_{p i}+\theta_{p 2} M+\varepsilon_{p i}, \\
& I_{i}^{*}=\delta_{0}+\delta_{1}\left(\log Y_{u i}-\log Y_{p i}\right)+\delta_{2} X_{i}+\delta_{3} Z_{i}+\delta_{4} M-\varepsilon_{i},
\end{aligned}
$$


where $\varepsilon_{\mathrm{u}} \sim \mathrm{N}\left(0, \sigma_{\mathrm{u}}^{2}\right), \varepsilon_{\mathrm{p}} \sim \mathrm{N}\left(0, \sigma_{\mathrm{p}}^{2}\right)$, and $\varepsilon \sim \mathrm{N}\left(0, \sigma_{\varepsilon}^{2}\right)$.

Following prior studies on offering yields of newly issued corporate bonds, ${ }^{18}$ the bond pricing equations include the following bond attribute and market condition variables:

Call = one if the bond is callable before maturity, zero otherwise;

Put $\quad=$ one if the bond is puttable before maturity, zero otherwise ${ }^{19}$

Sinking Fund $=$ one if the bond has a sinking fund provision, zero otherwise;

Junior $=$ one if the bond is a subordinated debt, zero otherwise;

Secured $=$ one if the bond is secured by firm assets, zero otherwise;

Maturity = natural log of the bond's term-to-maturity in years;

Proceeds $=$ natural $\log$ of the dollar size of the bond issue in millions;

Rating $=1,2,3,4, \ldots, 10,11$ if rated Aaa1, Aaa, Aa1, Aa2, ..., Baa2, Baa3, respectively by Moody's, 4 and 10 for NAIC-1 and NAIC-2 rated private placements, respectively; ${ }^{20}$

Treasury $=$ the ten-year constant-maturity Treasury bond yield at the offering date; and Volatility = standard deviation of the daily ten-year constant-maturity Treasury bond yield over a 20-trading-day period immediately prior to the offering date.

In the private placement model, we include a dummy variable, Switcher, which equals one if the private placement bond is issued by a switcher and zero otherwise, to distinguish between switchers' and nonswitchers' private placements. We also include time-effect dummy variables

18 See for example, Ederington (1975), Fabozzi and West (1981), Kidwell, Marr, and Thompson (1984), and Sorensen (1979).

${ }^{19}$ Using dummy variables to control for the incidence of call and put options is somewhat imprecise, but we do not have the necessary information to compute the optionadjusted spread for our sample bonds.

${ }^{20}$ As discussed later, below investment grade issues are not used to fit the model. 
in both pricing models to control for systematic market effects.

The exogenous variables for the issuance choice equation include the variable Firm Size which equals the natural log of the total assets of the issuing firm, and five previously defined variables: Maturity, Proceeds, Rating, Treasury, and Volatility. The variables Firm Size and Rating capture the firm's agency cost of debt and are expected to affect the firm's reservation yield differential and, hence, its debt choice. We allow the variable Proceeds to influence debt choice due to the economies of scale in issuing large debt issues, as part of the flotation costs are fixed costs that do not vary with issue size. The variable Maturity may also influence debt choice as private placement bonds are more flexible for renegotiation before maturity than public bonds. The variables Treasury and Volatility test the effects of market conditions on borrowing choice [Blackwell and Kidwell (1988)].

In our model, we observe the exogenous variables, the type of bond issue, and the dependent variables $\mathrm{Y}_{\text {ui }}$ or $\mathrm{Y}_{\mathrm{pi}}$. The observed yield spread depends on the bond type; we observe $Y_{p i}$ when $I_{i}=1$ and $Y_{\text {ui }}$ when $I_{i}=0$, but never both. This is a simultaneous equations model involving qualitative and limited dependent variables. In general, the bond pricing equations cannot be consistently estimated by ordinary least squares using the observed yield spreads because $\mathrm{E}\left(\varepsilon_{\mathrm{u}} \mid \mathrm{I}_{\mathrm{i}}=0\right) \neq 0$ and $\mathrm{E}\left(\varepsilon_{\mathrm{p}} \mid \mathrm{I}_{\mathrm{i}}=1\right) \neq 0$. Consistent estimators for this type of selfselection model are discussed in Heckman (1976) and Lee (1978) using a two-stage procedure. We estimate our model using the more efficient Full Information Maximum Likelihood (FIML) method.

Since 99 percent of our sample public bonds are of investment grade quality, and over 90 percent of below-investment grade private placement bonds are issued by non-switchers, we have 
a very unbalanced panel of below investment grade bonds. In estimating our model, we include only investment grade bonds from both the public and private samples, and exclude all belowinvestment grade bonds.

\section{B. The Results}

Table 4 presents the FIML estimates of the two bond pricing equations. The R-squares for the private placement and public bond models from the second stage regressions are 0.37 and 0.54 , respectively. ${ }^{21}$ The coefficient of Call is insignificant for public bonds but is significantly negative for private placements. The negative effect of Call on private placement yields may seem puzzling. One explanation is that issuers of private placement bonds that have restrictive covenants may demand a call option mainly to protect against future inflexibility rather than against interest rate declines. In particular, the majority of callable private placements have expensive makewhole call premium to protect the lenders from prepayment risk. Thus, the makewhole call option by itself may actually be valuable to the lender simply due to the rich call premium.

The coefficient of Put is significantly negative for public bonds, indicating that the put option is valuable to public bondholders for protection against event risks. However, the variable Put has a negative sign but is insignificant in the private placement model.

The coefficient of Sinking Fund is significantly positive for both private and public bonds, indicating that riskier bonds are more likely to have sinking fund provisions. The coefficient of Junior is insignificant. The significantly positive coefficient of Secured for private

21 In the final stage, both bond pricing equations were estimated jointly with the selection equation in one step so that there are no separate R-squares for the final estimates of the individual pricing equations. 
placements suggests that riskier bonds are more likely to be secured by firm assets. ${ }^{22}$ The findings indicate that both Sinking Fund and Secured appear to reflect the underlying credit risk of the borrower, as opposed to trading off bond yield against contract features.

The coefficient of Term-to-Maturity is significantly positive for public bonds, but is significantly negative for private placement issues. The positive effect of maturity on public bond yields suggests an additional risk premium demanded by investors to hold longer maturity publicly traded corporate bonds. In the private placement model, the negative effect of maturity on bond yield may be capturing the self-selection between maturity and credit risk, where high risk borrowers are less able to issue longer term debts. ${ }^{23}$

The coefficient of Proceeds is significantly negative for public bonds, but is significantly positive for private placements. This result suggests that in publicly offered bonds, a larger bond issue results in a deeper secondary market, which tends to lessen the bond's liquidity risk. On the other hand, the lack of a secondary market for private placement bonds may lead investors to demand a higher risk premium for holding a larger private bond issue.

The coefficient of Bond Rating is significantly positive for both public and private bond issues, confirming that riskier bonds have significantly higher yield spreads than less risky bonds. Note that the point estimate of this coefficient in the public bond model is more than three times

${ }^{22}$ Berger and Udell (1990) also found that riskier loans are more likely to be secured by collateral.

${ }^{23}$ Note that the Moody's or S\&P bond ratings for public bonds have a finer grid than the NAIC rating for private placements, so that the contract variables in the private placement model have a greater propensity to reflect the underlying credit risk of the borrower than the public bond model. This is another reason for fitting two separate bond pricing models for the two different types of bonds. 
the point estimate in the private placement model, indicating a much steeper trade off between bond yield spreads and credit risk ratings for public bonds than for private issues. This relationship is consistent with private placement bonds being more effective in controlling credit risk exposure than public market bonds because of their stronger covenant provisions and direct loan monitoring.

The significantly negative coefficient of Treasury indicates that bond yield spreads tend to decline with the level of interest rates. This reflects the relationship between credit spreads and the business cycle, where credit spreads tend to be highest at the bottom of the business cycle when interest rates are low, and vice versa. The coefficient of Volatility is insignificant, indicating that bond yield spreads in our sample are not determined by bond market volatility.

In the private placement model, the coefficient of Switcher is significantly negative. The finding suggests that firms that access the public debt market pay significantly less on their private placement bonds than firms that do not. This cost saving on private debt enjoyed by switchers is consistent with the cross-monitoring by public bondholders, as suggested by Booth (1992).

At the bottom of Table 4, we report the coefficient of the selectivity variable in the second stage estimation. It is significant for the public bond pricing equation, confirming the presence of a selection effect among public bond issuers. The coefficient of the selectivity variable, however, is insignificant in the private placement model.

\section{Issuance Choice and Cost Savings}

The two separate bond pricing models allow calculation of cost savings between the two bond markets for the sample borrowers. For private placement bonds, we estimate their public 
yield spreads using the public bond pricing model, i.e.,

$$
\begin{aligned}
& \text { Estimated public yield spread }=e^{\hat{\mu}_{\mathrm{ui}}} \\
& \hat{\mu}_{\mathrm{ui}}=\log \mathrm{Y}_{\mathrm{ui}}=\hat{\theta}_{\mathrm{uo}}+\hat{\theta}_{\mathrm{u} 1} Z_{\mathrm{pi}}+\hat{\theta}_{\mathrm{u} 2} \mathrm{M} .
\end{aligned}
$$

We then subtract the observed private placement yield spread from the estimated public yield spread to compute the cost savings of issuing bonds privately rather than publicly. Panel A of Table 5 shows that based on investment grade firms, on average, switchers save 6 basis points by issuing bonds privately rather than publicly, but it is not statistically significant. Non-switchers, however, on average save 38 basis points by issuing bonds privately, which is significant at the 1 percent level. The non-parametric Wilcoxon signed rank statistic also indicates that the cost saving is statistically significant. Overall, yield spreads of private placements on average are 30 basis points cheaper than otherwise similar public offerings, and the difference is significant. Note that the cost comparison is based on only the yield spread differences before flotation costs. The total cost savings of issuing bonds privately would be even larger to the extent that the flotation costs for private placements are expected to be smaller than public offerings.

For publicly offered bonds, we treat the borrower as a switcher and estimate the private placement yield spread using the private placement bond pricing model, i.e.,

$$
\begin{aligned}
& \text { Estimated private placement yield spread }=\mathrm{e}^{\hat{p}_{\mathrm{pi}}} \\
& \hat{\mu}_{\mathrm{pi}}=\log \mathrm{Y}_{\mathrm{pi}}=\hat{\theta}_{\mathrm{po}}+\hat{\theta}_{\mathrm{p} 1} \mathrm{Z}_{\mathrm{ui}}+\hat{\theta}_{\mathrm{p} 2} \mathrm{M} .
\end{aligned}
$$

We subtract the observed public bond yield spread from the estimated private yield spread to compute the cost savings of issuing bonds publicly instead of privately for public bond issuers. 
The results are shown in Panel B of Table 5. On average, borrowing firms save 39 basis points by issuing bonds publicly instead of privately, and the cost saving is statistically significant. However, the net cost savings of issuing bonds publicly would probably be less than reported here after accounting for the difference in flotation costs.

One issue remains unsettled, namely, the motivation for switchers to issue bonds in the private market, since doing so does not seem to produce significant cost savings. To shed light on switchers' bond issuance decisions, we estimate the structural form of the bond selection equation with all public bonds and switchers' private placement bonds. In essence, we estimate the modified choice equation in (7) using the estimated yield difference from the two bond pricing models as an explanatory variable. The dependent variable is a binary variable which equals one for private placements and zero for public issues. The explanatory variables are: Firm size, Term-to-Maturity, Proceeds, Treasury, Volatility, Bond Rating, Yield Difference, Debt Ratio, Q Ratio, and time-effect dummies. ${ }^{24}$ Debt Ratio is the issuing firm's debt-to-asset ratio and it measures the borrowing firm's financial leverage at the time of borrowing, which reflects its agency cost of debt and hence its demand for financial contracting. Q Ratio is the ratio of the issuing firm's market value equity to book value equity and it captures the firm's future growth opportunities; firms with high growth options may have higher agency costs of debt due to difficulty in bonding and monitoring.

The Probit estimates of the bond selection equation are shown in Table 6. The coefficient

${ }^{24}$ Debt Ratio and Q Ratio are added to the selection equation in (7) to improve the model once we exclude non-switchers' private placements from the estimation. Omitting these two variables from equation (7) (due to lack of data for non-switchers) would not bias the results since they are not correlated with the right-hand-side variables. The two variables are calculated from data in Compustat. 
of Firm Size is significantly negative. Although the size distributions between switchers and public bond issuers are similar (as shown in Table 3), the multivariate analysis indicates that private placement bonds are less likely to be issued by larger firms. The significantly negative coefficient of Proceeds confirms that larger bond issues are less likely to be privately placed. This is consistent with the scale economies of issuing bonds in the public market. The coefficient of Bond Rating is significantly negative. The finding indicates that among investment grade borrowers, firms with lower credit quality are less likely to issue bonds privately, perhaps to avoid the tight covenants in private placements once they gain access to the public bond market. The coefficient of Yield Difference has the positive sign but is insignificant. This is consistent with the earlier finding that switchers who issue private placement bonds do not seem to be motivated by the potential cost difference between the two markets. The coefficient of Debt Ratio is significantly positive. This finding suggests that firms with high financial leverage are more likely to issue bonds privately, indicating that a firm's borrowing choice reflects its underlying agency costs of debt and hence its demand for financial contracting. The coefficients

of the remaining variables, including Maturity, Treasury, Volatility, and Q-Ratio, are insignificant. In summary, the results in Table 6 suggest that switchers choose to issue bonds privately when the issue size is small, and when the financial leverage, and hence the agency costs of debt, is high.

\section{Conclusion}

This paper compares the structure and pricing of corporate bonds that are privately placed versus those that are offered to the public, and then examines firms' choice between issuing 
bonds privately verus publicly. The financial contracting in private placement bonds is quite unique due to the relatively ease of future renegotiation and direct credit monitoring. As such, the covenants in private placement bonds can be more restrictive compared to the relatively inflexible publicly offered bonds. Thus, private placements provide a bonding mechanism that is arguably much stronger than the bonding mechanism in public issues. Using micro data on a large sample of privately placed and publicly offered corporate bonds, our results suggest that private placement bonds indeed are more likely to have restrictive covenants than public issues. This is true even for the sub-sample of private placement bonds issued by borrowers who also accessed the public bond market in the past.

Among the issuers of private placement bonds, firms that borrow exclusively from the private market (or non-switchers) tend to be both riskier and smaller. This suggests that small and risky borrowers facing relatively high agency costs of debt demand stronger financial contracting in private placements to mitigate their incentive problems. While non-switchers may be systematically different from public bond issuers, it is an interesting question to study what motivates switchers, i.e., firms that issue bonds both publicly and privately, issuance choice.

In fitting two separate bond yield spread models for private placements and public issues with the adjustment for self-selection, we find important qualitative differences in the determinants of bond yield spreads across the two bond markets, including both the term-tomaturity and the bond issue size. They may stem simply from the different institutional arrangements between the two bond markets, such as one has a secondary market and the other has not, and one involves securities registration and underwriting and the other do not. Interestingly, we find the effect of bond rating on bond yield spread to be much larger in the 
public market than in the private market, which seems to be consistent with the more effective bonding and monitoring mechanism in the private placement market in reducing the credit risk premium.

Finally, we find evidence that borrowers self-select their debt issuance choice to minimize financing costs. However, switchers that issue debt in both markets do not realize significant cost savings by issuing bonds in the private market. Upon further investigation into switchers' debt choice, we find that smaller bond issues are more likely to be privately placed, indicating the presence of scale economies in issuing bonds in the public market. We also find that the higher the debt-to-asset ratio of the borrowing firm, the more likely the firm would issue bonds privately rather than publicly, indicating that firms with high agency costs of debt would prefer the financial contracting in private placements. 


\section{Appendix 1: An example of a private placement bond}

This appendix presents a summary of the proposed terms of one of the sample private placement bonds issued in May 1991 by a privately held, highly leveraged company; for confidentiality, the company is called XYZ, Inc. and the names of the principals are disguised.

\section{$\underline{\text { Summary of proposed terms for XYZ, Inc. }}$}

$\underline{\text { Amount }} \$ 25,000,000$

$\underline{\text { Rate }} \quad 15.85 \%$, payable quarterly $\quad \underline{\text { Term }} \quad 12$ years

Takedown June, $1991 \quad \underline{\text { life }} 9$ years

Date of

circle May 14, $1991 \quad$ Duration 5 years

Interpolated 9-year Treasury on Date of circle $8.04 \%$

Security The Notes and bank debt will be secured, pari passu, by (i) accounts receivable and inventory, (ii) $100 \%$ of the stock of the company, (iii) a first lien on all tangible assets, (iv) assignment of a key man life insurance policy on John Smith and, (v) an assignment of proceeds from XYZ, Inc. Equity Agreement.

Guarantors John Smith and David Brown will provide an unconditional joint and several guaranty of the prompt payment of the Notes.

Mandatory The Company will make seven annual payments beginning in 1997 of $\$ 3.571$ redemption million, resulting in an average life of nine years.

Optional The Notes are non-callable for four years. Thereafter, the Company may redemption prepay the Notes, in whole, or in part at a price equal to the greater of (i) par or (ii) the net present value of the remaining principal and interest payments due on the Notes discounted by the yield on U. S. Treasuries of a maturity comparable to the remaining weighted average life of the Notes, plus 50 basis points ("Makewhole Price").

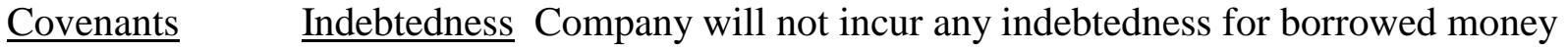
except for (i) indebtedness under the senior secured bank facility, senior secured bank term loan, and the Notes, (ii) subordinated indebtedness owing to Adam Gardner in an amount not greater than $\$ 7.25$ million, under terms acceptable to the Investors, and (iii) purchase money debt such that the 
aggregate amount does not exceed $\$ 500,000$.

Liens and encumbrances No creation by the Company of any liens or encumbrances subject to permitted exceptions.

Restricted payments Company will not (i) declare or pay any dividend on its capital stock, (ii) make any distribution or loan to stockholders or affiliates, (iii) purchase or redeem any of its capital stock, or (iv) defease or redeem any subordinated indebtedness except with the proceeds of or in exchange for common stock (items (i) through (iv) above to be termed "Restricted Payments") unless, after giving effect thereto, (v) the sum of such Restricted Payments in any fiscal year is not in excess of $\$ 500,000$ and (vi) the ratio of Senior Debt to earnings before interest, depreciation and amortization, and taxes ("EBITD") is less than 3.50; provided however, that no restricted payment may be made, if after giving effect thereto, an event of default exists. No Contingent Payment or Subordinated Note payment may be made, if after giving effect thereto, an event of default exists.

Amendment of subordinated indebtedness Company will not consent to any amendment or modification to any agreements or instruments evidencing subordinated indebtedness without the prior written consent of the Noteholders.

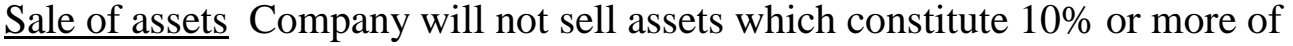
the assets of Company.

EBITD to senior interest ratio The ratio of EBITD to senior cash interest expense (measured on a rolling four quarter basis) shall not be less than:

$\underline{\text { Period }} \quad \underline{\text { Minimum ratio }}$

Closing through 12/31/92 $\quad 1.75$

$1 / 1 / 93$ through $12 / 31 / 93 \quad 1.95$

$1 / 1 / 94$ through $12 / 31 / 95 \quad 2.25$

$1 / 1 / 94$ through $12 / 31 / 95 \quad 2.50$

EBITD to fixed charge ratio The ratio of EBITD to fixed charges (measured on a rolling four quarter basis) shall not be less than:

$\underline{\text { Period }} \quad \underline{\text { Minimum ratio }}$

Closing through 12/31/92 $\quad 1.25$

Thereafter $\quad 1.35$ 
Fixed charges will be defined to be the sum of (i) interest expense, (ii) scheduled principal payments, (iii) operating lease expenses, (iv) rental expenses and (v) capital lease payments.

Senior debt to EBITD The ratio of senior debt to EBITD on a rolling four quarter basis will not be greater than:

\section{$\underline{\text { Period } \quad \underline{\text { Maximum ratio }}}$}

Closing through $12 / 31 / 91$

$1 / 1 / 92$ through $12 / 31 / 92$

$1 / 1 / 93$ through $12 / 31 / 93$

$1 / 1 / 94$ through $12 / 31 / 94$

$1 / 1 / 95$ through $12 / 21 / 95$

Thereafter
6.25

5.75

5.10

4.75

4.35

4.00

Senior debt will be defined as indebtedness for borrowed money, capitalized lease obligations and contingent liabilities (e.g. guarantees, letters of credit, etc.) not expressly subordinate to the Notes.

Loans, investments and advances Company will not make any loan to or acquire any securities of or other interest in any person except for (i) loans and advances to stockholders, officers or employees in an amount up to $\$ 750,000$ and (ii) temporary cash investments of acceptable credit quality.

Current ratio The ratio of consolidated current assets to consolidated current liabilities (excluding funded indebtedness) shall not be less than 1.20 to 1.00.

Equity agreement Company will not sell, assign, transfer, or convey the Equity Agreement.

Change of control Upon a change of control, defined as a change in $10 \%$ of the ownership of any individual, the holders of the Notes may request prepayment of the Notes at the greater of par or the Makewhole Price. John Smith must maintain in excess of $51 \%$ ownership. 


\section{References}

Barnea, A., R. Haugen, and L. Senbet, 1980, A rationale for debt maturity structure and call provisions in the agency theory framework, Journal of Finance 35, 1223-1234.

Beneish, M. and E. Press, 1993, Costs of technical violation of accounting-based debt covenants, The Accounting Review 68, 233-257.

Berger, A. and G. Udell, 1990, Collateral, loan quality, and bank risk, Journal of Monetary Economics 25, 21-42.

Berlin, M. and J. Loeys, 1988, Bond covenants and delegated monitoring, Journal of Finance 43, 397-412.

Berlin, M. and L. Mester, 1992, Debt covenants and renegotiation, Journal of Financial Intermediation 2, 95-133.

Blackwell, D. and D. Kidwell, 1988, An investigation of cost differences between public sales and private placements of debt, Journal of Financial Economics 22, 253-278.

Bodie, Z. and R. Taggart, 1978, Future investment opportunities and the value of the call provision on a bond, Journal of Finance 33, 1187-1200.

Booth, J., 1992, Contract costs, bank loans, and the cross-monitoring hypothesis, Journal of Financial Economics 31, 25-41.

Carey, M., S. Prowse, J. Rea, and G. Udell, 1993, The economics of private placements: A new look, Financial Markets, Institutions and Instruments 2, 1-67.

Cantillo, M. and J. Wright, 2000, How do firms choose their lenders? An empirical investigation. Review of Financial Studies 13, 155-189.

Chemmanur, T. and P. Fulghieri, 1994, Reputation, renegotiation, and the choice between bank loans and publicly traded debt, Review of Financial Studies 7, 475-506.

Chen, K. and K. Wei, 1993, Creditors' decisions to waive violations of accounting-based debt covenants, The Accounting Review 68, 218-232.

Denis, D. J. and V. T. Mihov, 2003, The choice among bank debt, non-bank private debt, and public debt: Evidence from new corporate borrowings, Journal of Financial Economics 70, 3-28.

Diamond, D., 1984, Financial intermediation and delegated monitoring, Review of Economic Studies 51, 393-414. 
Diamond, D., 1991, Monitoring and reputation: The choice between bank loans and directly placed debt, Journal of Political Economy 99, 688-721.

Ederington, L., 1975, Uncertainty, competition, and costs in corporate bond underwriting, Journal of Financial Economics 2, 71-94.

El-Gazzar, S. and V. Pastena, 1990, Negotiated accounting rules in private financial contracts, Journal of Accounting and Economics 12, 381-396.

Fabozzi, F. and R. West, 1981, Negotiated versus competitive underwritings of public utility bonds: Just one more time, Journal of Financial and Quantitative Analysis 16, 323-339.

Fenn, G., 2000, Speed of issuance and the adequacy of disclosure in the 144A high-yield debt market, Journal of Financial Economics 56, 383-406.

Hawkins, G., 1982, Essay on non-publicly issued debt: Revolving credit agreements and the pricing of privately placed debt, Unpublished Ph.D. dissertation, M.I.T.

Heckman, J., 1976, The common structure of statistical models of truncation, sample selection, and limited dependent variables and a simple estimator for such models, Annals of Economics and Social Measurement, 5, 475-492.

Houston, J. and C. James, 1996, Bank information monopolies and the mix of private and public debt claims, Journal of Finance 51, 1863-1889.

James, C., 1987, Some evidence on the uniqueness of bank loans, Journal of Financial Economics 19, 217-235.

Jensen, M. and W. Meckling, 1976, Theory of the firm: Managerial behavior, agency costs and ownership structure, Journal of Financial Economics 3, 305-360.

Kidwell, D., W. Marr, and R. Thompson, 1984, SEC rule 415: The ultimate competitive bid, Journal of Financial and Quantitative Analysis 19, 183-195.

Krishnaswami, S., P. Spindt, and V. Subramaniam, 1999, Information asymmetry, monitoring, and the placement structure of corporate debt, Journal of Financial Economics 51, 407-434.

Laber, G., 1992, Bond covenants and financial management: Some comparisons of public and private debt, University of Vermont Working Paper.

Lee, L., 1978, Unionism and wage rates: A simultaneous equations model with qualitative and limited dependent variables, International Economic Review 19, 415-433. 
Lummer, S. and J. McConnell, 1989, Further evidence on the bank lending process and the capital market response to bank loan agreements, Journal of Financial Economics 25, 99-122.

Myers, S., 1977, Determinants of corporate borrowing, Journal of Financial Economics 5, 147175.

Robbins, E. and J. Schatzberg, 1986, Callable bonds: A risk-reducing signaling mechanism, Journal of Finance 41, 935-949.

Smith, C. and J. Warner, 1979, On financial contracting: An analysis of bond covenants, Journal of Financial Economics 7, 117-161.

Society of Actuaries, 1996, 1986-1992 credit risk loss experience study: Private placement bonds, published study by the Society of Actuaries, Schaumburg, Illinois.

Sorensen, E., 1979, The impact of underwriting method and bidder competition upon corporate bond interest cost, Journal of Finance 34, 863-870.

Thatcher, J. 1985, The choice of call provision terms: Evidence of the existence of agency costs of debt, Journal of Finance 40, 549-561.

Zinbarg, E., 1975, The private placement loan agreement, Financial Analysts Journal 31, 33-52.

Zwick, B., 1980, Yields on privately placed corporate bonds, Journal of Finance 35, 23-29. 
Table 1: Descriptive statistics for privately placed and publicly offered corporate bonds.

In each cell are mean and median (in parentheses) for continuous variables, and, percent and number (in parentheses) for discrete variables. The tests for similar distributions in contract characteristics across samples are the Wilcoxon Rank Sum test for continuous variables and the Chi-square test for discrete variables. Switchers are firms that have publicly issued bonds on their balance sheets at the time of the private placement.

\begin{tabular}{|c|c|c|c|c|}
\hline & \multicolumn{3}{|c|}{ Private placement bonds } & \multirow{2}{*}{$\begin{array}{c}\text { Publicly } \\
\text { offered bonds }\end{array}$} \\
\hline & Full sample & $\begin{array}{l}\text { Issued by } \\
\text { switchers }\end{array}$ & $\begin{array}{c}\text { Issued by non- } \\
\text { switchers } \\
\end{array}$ & \\
\hline Yield spread $^{\mathrm{c}}$ & $\begin{array}{l}2.02 \%{ }^{a} \\
(1.55 \%)\end{array}$ & $\begin{array}{l}1.32 \%{ }^{\mathrm{a}, \mathrm{b}} \\
(1.24 \%)\end{array}$ & $\begin{array}{l}2.18 \%{ }^{a, b} \\
(1.70 \%)\end{array}$ & $\begin{array}{l}1.13 \%{ }^{a} \\
(1.05 \%)\end{array}$ \\
\hline $\begin{array}{l}\text { Issue size } \\
\text { (in \$million) }\end{array}$ & $\begin{array}{l}\$ 65.11^{a} \\
(\$ 40.0)\end{array}$ & $\begin{array}{l}\$ 79.16^{\mathrm{a}} \\
(\$ 48.0)\end{array}$ & $\begin{array}{l}\$ 61.88^{a} \\
(\$ 40.0)\end{array}$ & $\begin{array}{l}\$ 154.31^{a} \\
(\$ 125.0)\end{array}$ \\
\hline $\begin{array}{l}\text { Term-to-maturity } \\
\text { (in year) }\end{array}$ & $\begin{array}{l}11.21^{\mathrm{a}} \\
(10.0)\end{array}$ & $\begin{array}{l}12.56^{b} \\
(12.0)\end{array}$ & $\begin{array}{l}10.90^{a, b} \\
(10)\end{array}$ & $\begin{array}{c}14.97^{\mathrm{a}} \\
(10)\end{array}$ \\
\hline Call provision & $\begin{array}{l}92.4 \%{ }^{\mathrm{a}} \\
(608)\end{array}$ & $\begin{array}{l}86.2 \%{ }^{a, b} \\
(106)\end{array}$ & $\begin{array}{l}93.8 \% \%^{a, b} \\
(502)\end{array}$ & $\begin{array}{l}40.4 \%{ }^{\mathrm{a}} \\
(664)\end{array}$ \\
\hline Makewhole call & $\begin{array}{l}60.5 \%{ }^{a} \\
(398)\end{array}$ & $\begin{array}{l}42.3 \%{ }^{a, b} \\
(52)\end{array}$ & $\begin{array}{l}64.7 \%{ }^{a, b} \\
(346)\end{array}$ & $\begin{array}{l}0 \% \\
(0)\end{array}$ \\
\hline Put provision & $\begin{array}{l}24.5 \%{ }^{\mathrm{a}} \\
(161)\end{array}$ & $\begin{array}{l}20.3 \% \\
(25)\end{array}$ & $\begin{array}{l}25.4 \%^{\mathrm{a}} \\
(136)\end{array}$ & $\begin{array}{l}3.1 \%{ }^{a} \\
(51)\end{array}$ \\
\hline Sinking fund & $\begin{array}{l}77.3 \%{ }^{\mathrm{a}} \\
(509)\end{array}$ & $\begin{array}{l}74.0 \%{ }^{a} \\
(91)\end{array}$ & $\begin{array}{l}78.1 \%^{a} \\
(418)\end{array}$ & $\begin{array}{l}10.2 \%^{\mathrm{a}} \\
(168)\end{array}$ \\
\hline Secured by Assets & $\begin{array}{l}32.5 \%{ }^{a} \\
(214)\end{array}$ & $\begin{array}{l}39.0 \% \\
(48)\end{array}$ & $\begin{array}{l}31.0 \%^{\mathrm{a}} \\
(166)\end{array}$ & $\begin{array}{l}22.4 \%{ }^{\mathrm{a}} \\
(368)\end{array}$ \\
\hline $\mathrm{N}$ & 658 & 123 & 535 & 1643 \\
\hline
\end{tabular}

${ }^{a}$ Indicates significant difference at the $1 \%$ level between the private placement sample and the public sample.

b Indicates significant difference at the $1 \%$ level between the sub-samples of switchers' and nonswitchers' private placement bonds.

${ }^{c}$ Yield spread is the offering yield-to-maturity over a similar maturity Treasury bond yield. 
Table 2: Credit risk ratings for privately placed and publicly offered corporate bonds.

For the private placement sample, credit ratings are from the rating system used by the National Association of Insurance Commissioners (NAIC) to assign mandatory security valuation reserves for insurance companies. For the public bond sample, Moody's bond ratings are converted to the equivalent NAIC ratings. NAIC 1 has the lowest credit risk. Switchers are firms that have publicly offered bonds on their balance sheets at the time of the private placement.

\begin{tabular}{lcccc}
\hline & \multicolumn{3}{c}{ Private placement bonds } & \multirow{2}{*}{$\begin{array}{c}\text { Publicly } \\
\text { offered bonds }\end{array}$} \\
\cline { 2 - 4 } & Full sample & $\begin{array}{c}\text { Issued by } \\
\text { switchers }\end{array}$ & $\begin{array}{c}\text { Issued by non- } \\
\text { switchers }\end{array}$ & \\
\hline NAIC 1 & $44.1 \%$ & $76.4 \%$ & $36.6 \%$ & $72.7 \%$ \\
NAIC 2 & $(290)$ & $(94)$ & $(196)$ & $(1194)$ \\
& $22.5 \%$ & $9.8 \%$ & $25.4 \%$ & $26.2 \%$ \\
NAIC 3 & $(148)$ & $(12)$ & $(136)$ & $(431)$ \\
& $3.3 \%$ & $0 \%$ & $4.1 \%$ & $1.0 \%$ \\
NAIC 4 & $(22)$ & $(0)$ & $(22)$ & $(16)$ \\
& $9.3 \%$ & $10.6 \%$ & $9.0 \%$ & $0.1 \%$ \\
NAIC 5 & $(61)$ & $(13)$ & $(48)$ & $(2)$ \\
& $20.8 \%$ & $3.2 \%$ & $24.9 \%$ & $0 \%$ \\
Weighted Average & $(137)$ & $(4)$ & $(133)$ & 1.28 \\
\hline NAIC Rating & 2.40 & 1.54 & 2.60 & 1643 \\
\hline N & 658 & 123 & 535 & \\
\hline
\end{tabular}

Chi-square test (p-value) that the distributions of NAIC rating is the same:

between the full sample of private placements and public issues: $\chi^{2}=565.7(<0.001)$

between switchers' private placements and public issues: $\chi^{2}=214.2(<0.001)$

between non-switchers' private placements and public issues: $\chi^{2}=653.1(<0.001)$. 
Table 3: Firm size of borrowers in the private placement and public bond markets.

Mean (median) is based on a sample of 658 private placement bonds issued by 466 firms and a sample of 1,643 publicly offered bonds issued by 414 firms. The test for similar distributions of total assets and annual sales across samples is the Wilcoxon Rank Sum test. Switchers are firms that have publicly offered bonds on their balance sheets at the time of the private placement.

\begin{tabular}{lcccc}
\hline & \multicolumn{3}{c}{ Private placement bonds } & \multirow{2}{*}{$\begin{array}{c}\text { Publicly } \\
\text { offered bonds }\end{array}$} \\
\cline { 2 - 4 } & Full sample & Switchers & Non-switchers & \\
\hline \multirow{2}{*}{$\begin{array}{l}\text { Total assets } \\
\text { (millions) }\end{array}$} & $\$ 2,454^{\mathrm{a}}$ & $\$ 6,827^{\mathrm{b}}$ & $\$ 1,421^{\mathrm{a}, \mathrm{b}}$ & $\$ 12,246^{\mathrm{a}}$ \\
Annual sales & $(\$ 401)$ & $(\$ 4,009)$ & $(\$ 311)$ & $(\$ 4,033)$ \\
(millions) & $\$ 2,145^{\mathrm{a}}$ & $\$ 4,929^{\mathrm{b}}$ & $\$ 1,488^{\mathrm{a}, \mathrm{b}}$ & $\$ 6,007^{\mathrm{a}}$ \\
$\mathrm{N}$ & $(\$ 472)$ & $(\$ 2,935)$ & $(\$ 312)$ & $(\$ 2,455)$ \\
\hline
\end{tabular}

${ }^{a}$ Indicates significant difference at the $1 \%$ level between the private placement sample and the public sample.

${ }^{\mathrm{b}}$ Indicates significant difference at the $1 \%$ level between the sub-samples of switchers and nonswitchers. 
Table 4: Full information maximum likelihood estimates of the switching regression model of private placement and publicly offered investment grade corporate bond yield spread.

Regression of yield spread in excess of a similar maturity Treasury bond yield on bond characteristics and market conditions, with adjustment for self-selection (see notes on next page). $\underline{\text { Standard errors are in parentheses. Coefficients of time-effect dummy variables are not reported. }}$

\begin{tabular}{|c|c|c|}
\hline Variable & Private Placement Bonds & Publicly Offered Bonds \\
\hline Call & $\begin{array}{l}-0.173 * * * \\
(0.056)\end{array}$ & $\begin{array}{c}0.011 \\
(0.024)\end{array}$ \\
\hline Put & $\begin{array}{l}-0.049 \\
(0.036)\end{array}$ & $\begin{array}{l}-0.631 * * * \\
(0.029)\end{array}$ \\
\hline Sinking Fund & $\begin{array}{l}0.130 * * * \\
(0.042)\end{array}$ & $\begin{array}{l}0.198 * * * \\
(0.037)\end{array}$ \\
\hline Junior & $\begin{array}{c}0.068 \\
(0.057)\end{array}$ & $\begin{array}{c}0.078 \\
(0.048)\end{array}$ \\
\hline Secured & $\begin{array}{l}0.127 * * * \\
(0.030)\end{array}$ & $\begin{array}{l}-0.052 \\
(0.032)\end{array}$ \\
\hline Term-to-Maturity & $\begin{array}{l}-0.120 * * \\
(0.047)\end{array}$ & $\begin{array}{l}0.223 * * * \\
(0.014)\end{array}$ \\
\hline Proceeds & $\begin{array}{l}0.051 * * * \\
(0.017)\end{array}$ & $\begin{array}{l}-0.099 * * * \\
(0.014)\end{array}$ \\
\hline Bond Rating & $\begin{array}{l}0.034 * * * \\
(0.006)\end{array}$ & $\begin{array}{l}0.122 * * * \\
(0.004)\end{array}$ \\
\hline Treasury & $\begin{array}{l}-0.073 * * * \\
(0.025)\end{array}$ & $\begin{array}{l}-0.091 * * * \\
(0.020)\end{array}$ \\
\hline Volatility & $\begin{array}{l}-0.106 \\
(0.260)\end{array}$ & $\begin{array}{c}0.013 \\
(0.152)\end{array}$ \\
\hline Switcher & $\begin{array}{l}-0.129 * * * \\
(0.043)\end{array}$ & \\
\hline $\begin{array}{l}\text { Selectivity Variable } \\
\text { (from second stage) }\end{array}$ & $\begin{array}{l}-0.011 \\
(0.027)\end{array}$ & $\begin{array}{l}0.154 * * * \\
(0.039)\end{array}$ \\
\hline $\mathrm{R}^{2}$ (from second stage) & 0.37 & 0.54 \\
\hline Number of Observations & 438 & 1625 \\
\hline
\end{tabular}

***,** Indicate significance at the $1 \%$ and $5 \%$ levels, respectively. 
Notes to Table 4:

The empirical model consists of the following three equations:

$$
\begin{aligned}
& \log \mathrm{Y}_{\mathrm{ui}}=\theta_{\mathrm{u} 0}+\theta_{\mathrm{u} 1} \mathrm{Z}_{\mathrm{ui}}+\theta_{\mathrm{u} 2} \mathrm{M}+\varepsilon_{\mathrm{ui}} \\
& \log \mathrm{Y}_{\mathrm{pi}}=\theta_{\mathrm{p} 0}+\theta_{\mathrm{p} 1} \mathrm{Z}_{\mathrm{pi}}+\theta_{\mathrm{p} 2} \mathrm{M}+\varepsilon_{\mathrm{pi}} \\
& \mathrm{I}_{\mathrm{i}}^{*}=\delta_{0}+\delta_{1}\left(\log \mathrm{Y}_{\mathrm{ui}}-\log \mathrm{Y}_{\mathrm{pi}}\right)+\delta_{2} \mathrm{X}_{\mathrm{i}}+\delta_{3} \mathrm{Z}_{\mathrm{i}}+\delta_{4} \mathrm{M}-\varepsilon_{\mathrm{i}}
\end{aligned}
$$

where $\varepsilon_{\mathrm{u}} \sim \mathrm{N}\left(0, \sigma_{\mathrm{u}}^{2}\right), \varepsilon_{\mathrm{p}} \sim \mathrm{N}\left(0, \sigma_{\mathrm{p}}^{2}\right)$, and $\varepsilon \sim \mathrm{N}\left(0, \sigma_{\varepsilon}^{2}\right)$.

In the first two equations, $\mathrm{Y}_{\mathrm{ui}}$ and $\mathrm{Y}_{\mathrm{pi}}$ are the public and private bond yield spread, respectively, for the ith firm. $\mathrm{Z}_{\mathrm{ui}}, \mathrm{Z}_{\mathrm{pi}}$ are the vectors of variables for bond attributes, including:

Call $=$ one if the bond is callable before maturity, zero otherwise;

Put = one if the bond is puttable before maturity, zero otherwise;

Sinking Fund $=$ one if the bond has a sinking fund provision, zero otherwise;

Junior $=$ one if the bond is a subordinated debt, zero otherwise;

Secured $=$ one if the bond is secured by firm assets, zero otherwise;

Maturity = natural log of the bond's term-to-maturity in years;

Proceeds $=$ natural $\log$ of the dollar size of the bond issue in millions;

Rating $=1,2,3,4, \ldots, 10,11$ for Aaa1, Aaa, Aa1, Aa2, ... Baa2, Baa3 rated public issues, respectively, 4 and 10 for NAIC-1 and NAIC-2 rated private placements, respectively; and

Switcher $=$ one if the private placement is issued by a switcher, zero otherwise.

$\mathrm{M}$ is the vector of variables for market condition, including time-effect dummies;

Treasury = the ten-year constant-maturity Treasury bond yield at the offering date; and

Volatility = standard deviation of the daily ten-year constant-maturity Treasury bond yield over a 20-trading-day period immediately prior to the offering date.

The third equation models bond selection: if $\mathrm{I}_{i}{ }^{*}>0$, then the ith firm issues private placement bonds; otherwise it issues public bonds. The exogenous variables for the selection equation include Firm Size which equals the natural log of the total assets of the issuing firm and the variables Maturity, Proceeds, Rating, Treasury, and Volatility as defined above. 
Table 5: Cost savings of issuing bonds privately versus publicly by investment grade firms

In panel A, cost saving equals predicted public bond yield spread, calculated from estimates in Table 4, minus observed private placement yield spread. In panel B, cost saving equals predicted private placement bond yield spread, calculated from estimates in Table 4, minus observed public bond yield spread.

\begin{tabular}{|c|c|c|c|c|}
\hline \multicolumn{5}{|c|}{$\begin{array}{l}\text { Panel A: Cost savings of issuing private placement bonds } \\
\text { for } 438 \text { private placement issues, in basis points }\end{array}$} \\
\hline & $\underline{\text { Mean }}$ & $\underline{\text { Median }}$ & $\frac{\text { \% Positive (Wilcoxon Signed }}{\underline{\text { Rank Statistic) }}}$ & $\underline{\mathrm{N}}$ \\
\hline Switchers & 6.6 & -4.9 & $48 \%(292.5)$ & 106 \\
\hline Non-switchers & $37.7 * * *$ & 15.6 & $55 \%(8143 * * *)$ & 332 \\
\hline All & $30.2 * * *$ & 9.9 & $54 \%\left(11931.5^{* * *}\right)$ & 438 \\
\hline \multicolumn{5}{|c|}{$\begin{array}{l}\text { Panel B: Cost savings of issuing bonds in the public market } \\
\text { for } 1,625 \text { public issues, in basis points }\end{array}$} \\
\hline$\underline{\text { Mean }}$ & $\underline{\text { Median }}$ & \multicolumn{3}{|c|}{$\frac{\text { \% Positive (Wilcoxon Signed Rank }}{\underline{\text { Statistic) }}}$} \\
\hline $39.0 * * *$ & 44.5 & \multicolumn{2}{|c|}{$77 \%(450865 * * *)$} & 1625 \\
\hline
\end{tabular}

*** Indicates significance at the $1 \%$ level. 
Table 6: Probit estimates of the private placement-public bond selection equation

The dependent variable, bond type, equals 1 for private placements and 0 for public issues. Firm Size is the natural log of total assets of the borrowing firm. Maturity is the natural log of the bond's term-to-maturity. Proceeds is the natural log of the dollar size of the bond issue. Rating equals 1, 2, 3, ... for Aaa1, Aaa, Aa1, ... rated public issues, respectively, and 4 and 10 for NAIC1 and NAIC-2 rated private placements, respectively. Treasury is the ten-year constant-maturity Treasury bond yield at the offering date. Volatility is the standard deviation of the daily ten-year constant-maturity Treasury bond yield over a 20-trading-day period immediately prior to the offering date. The potential yield spread difference is computed using the bond pricing equations' coefficient estimates reported in Table 4. Debt Ratio is the borrowing firm's debt-toasset ratio. Q Ratio is the ratio of the borrowing firm's market value equity to book value equity. Standard errors are in parentheses. Coefficients of time-effect dummy variables are not reported.

\begin{tabular}{|c|c|}
\hline \multicolumn{2}{|c|}{ Dependent Variable $=1$ for private placement and 0 for public offering } \\
\hline Firm Size & $\begin{array}{l}-0.511 * * * \\
(0.065)\end{array}$ \\
\hline Maturity & $\begin{array}{l}-0.078 \\
(0.198)\end{array}$ \\
\hline Proceeds & $\begin{array}{l}-0.231 * * * \\
(0.088)\end{array}$ \\
\hline Treasury & $\begin{array}{c}0.116 \\
(0.171)\end{array}$ \\
\hline Volatility & $\begin{array}{c}1.319 \\
(1.320)\end{array}$ \\
\hline Rating & $\begin{array}{l}-0.490 * * * \\
(0.065)\end{array}$ \\
\hline$\hat{\ln } \hat{Y}_{\text {public }}-\ln \hat{Y}_{\text {private }}$ & $\begin{array}{c}0.169 \\
(0.427)\end{array}$ \\
\hline Debt Ratio & $\begin{array}{l}4.983^{* * *} \\
(0.685)\end{array}$ \\
\hline Q Ratio & $\begin{array}{l}-0.001 \\
(0.045)\end{array}$ \\
\hline Chi-Squared & $342.2 * * *$ \\
\hline Number of Observations & 1731 \\
\hline
\end{tabular}

*** Indicate significance at the $1 \%$ level. 